\title{
O doskonałości naukowej i uniwersytetach badawczych w związku z Ustawą $2.0^{1}$
}

STRESZCZENIE. Od połowy 2016 r. w Polsce trwa debata na temat koniecznych zmian w systemie nauki i szkolnictwa wyższego. Jej elementem jest dyskusja nad tym, jak zwiększyć poziom doskonałości naukowej, rozpoznawanie polskiej nauki na świecie oraz jej umiędzynarodowienie. W tekście zaproponowano kilka rozwiązań pozwalających osiągnąć te cele. Chodzi w szczególności o zwiększenie liczby prestiżowych grantów międzynarodowych realizowanych na polskich uczelniach, w tym tych przyznawanych przez Europejską Agencję ds. Badań. Zaproponowano także kryteria wyboru uczelni, które mogłyby uzyskać dodatkowe finansowanie na przekształcenie się w uniwersytety badawcze. Byłyby one oparte na pokazaniu ścieżki zmian, jakie mogą zostać przeprowadzone, ale wymagają dodatkowego finansowania. Głównym celem tekstu jest zaproponowanie konkretnych rozwiązań, jakie mogłyby zostać zastosowane w nowej legislacji regulującej kwestie nauki i szkolnictwa wyższego.

SŁOWA KLUCZOWE: nauka, grant Europejskiej Rady ds. Badań, uniwersytet badawczy, doskonałość naukowa.

\section{Wstęp}

W polskim społeczeństwie narasta przekonanie, że polskie uczelnie wyższe oraz inne ośrodki naukowe coraz bardziej zwiększają dystans do wiodących uniwersytetów światowych. Nie zmienia tego zasadniczo wzrost pozycji Uniwersytetu Warszawskiego w ostatniej edycji rankingu szanghajskiego oraz pojawienie się na nim, na miejscach od 500 do 800, czterech polskich uczelni. Jako porównanie brane są najlepsze uczelnie amerykańskie i europejskie. Za wzór stawiane są brytyjskie Oxford czy Cambridge oraz amerykańskie Harvard czy Stanford. To prawda, in-

\footnotetext{
${ }^{1}$ Tekst wyraża prywatne poglądy autora.
} 
stytucje te zajmują najwyższe pozycje w rankingach. Tymczasem polskie uczelnie plasują się na środkowych lub ostatnich miejscach najważniejszych zestawień najlepszych uczelni na świecie. Należy jednak pamiętać, że znalezienie się w takim gronie to już wyraz ogromnego docenienia i nobilitacji. Jedynie ok. 1,5\% wszystkich uczelni na świecie w ogóle znajduje miejsce w rankingach. Dla porównania, byłoby świetnie, gdyby np. dwie, trzy polskie firmy znalazły się w 1,5\% najbardziej konkurencyjnych przedsiębiorstw świata, a kilka polskich klubów piłkarskich grałoby regularnie w Lidze Mistrzów. Z Polską nauką nie jest tak źle, jak często przedstawia się to $\mathrm{w}$ mediach. $\mathrm{W}$ naszym regionie zaliczamy się do absolutnych liderów. Porównywalne osiągnięcia z najlepszymi polskimi uniwersytetami mają tylko Uniwersytet Karola w Pradze, Estoński Tartu czy Uniwersytet w Lubljanie. Dobrze to wiedzieć, rozmawiając o polskiej nauce. Nie oznacza to jednak, że nie powinno i nie może być lepiej. Jeżeli spoczniemy na laurach, to możemy wypaść z elity i przestać się liczyć na świecie. Dlatego mój krótki tekst nie jest obroną obecnego stanu, ale nawoływaniem do zmian i podjęcia niełatwej próby zmierzenia się z wyzwaniami przyszłości. Spróbuję skupić się na kwestiach doskonałości naukowej i pokazać to na kilku przykładach. Zacznę od granatów Europejskiej Rady ds. Badań, czyli najważniejszych projektów badawczych, jakie są realizowane w Unii Europejskiej.

\section{Granty ERC - dlaczego opłaca się o nie zawalczyć}

Kiedy uczestniczę w różnych spotkaniach mających na celu prezentację uczelni, kilka rzeczy wydaje mi się bardzo charakterystycznych. Prezentacje powszechnie przygotowywane w programie Power Point czy wyświetlane filmy promocyjne maja kilka cech wspólnych. Na pierwszych slajdach czy w pierwszych sekundach filmu zawarte są informacje o liczbie studentów, rocznym budżecie czy nowo oddanych laboratoriach. Zaraz po nich pojawia się informacja o uzyskanych grantach Europejskiej Rady ds. Badań oraz realizowanych projektach z innych programów Horizon 2020. To w powszechnym odczuciu jest wyznacznik doskonałości naukowej. Dlatego też w żywotnym interesie polskich uniwersytetów jest staranie się o granty „europejskie”, mimo że warunki ich realizacji, ustalone na poziomie unijnym, często zniechęcają do ubiegania się o nie. Przy obecnych uregulowaniach jest to bowiem bardzo trudne i wymaga nie tylko pełnej mobilizacji administracji uczelni odpowiedzialnej za pozyskiwanie i obsługę badań, ale również przekonania badaczy, którzy mogą uzyskać taki prestiżowy grant, żeby o niego wystąpili. Niezmiernie trudne jest także przyciągnięcie do Polski cudzoziemca, który chciałby starać się, a później realizować taki grant na polskiej uczelni. Jeżeli moja diagnoza jest słuszna, a jestem przekonany, że tak jest, na podstawie empirycznych dowodów z codziennej pracy, to konieczne jest wykorzystanie obecnej dyskusji nad zmianami 
w polskiej nauce i szkolnictwie wyższym do tego, aby w tej dziedzinie nastąpił znaczący postęp. Oto kwestie, na które należy zwrócić uwagę:

- System wspierania uczelni powinien zakładać „nagrodę” za uzyskiwanie środków z unijnego budżetu przeznaczonych na naukę. Zasada euro za euro wydaje się tu jak najbardziej godna poparcia.

- Powinny zniknąć ograniczenia w postaci konieczności uzyskiwania habilitacji przez najwybitniejszych badaczy, tak by stali się oni samodzielnymi naukowcami. To pozwoliłoby nam stworzyć sieć mobilności z innymi uczelniami na świecie, gdzie po prostu habilitacji nie ma. Obecnie „polski” doktor nie ma problemu z zatrudnieniem na stanowisku profesora za granicą. Tymczasem „zagraniczny” doktor, który potwierdził już swoją doskonałość naukową, musi przechodzić często długą i w pewnym stopniu upokarzającą dla niego procedurę habilitacyjną. Dlatego też w wielu przypadkach mamy mobilność tylko w jedną stronę, co jest dla nas po prostu niekorzystne.

- System organizacji badań na uczelniach powinien być jak najbardziej elastyczny. Powinny być one realizowane w zespołach badawczych, którym uczelnia niejako „wynajmuje” powierzchnie i administrację dla obsługi. Obie muszą być na jak najwyższym poziomie. Pozwoliłoby to ograniczyć problemy, jakie napotykają zewnętrzni badacze, którzy chcą ubiegać się i realizować grant na danej uczelni, ale tak naprawdę to nie ma dla nich miejsca, ponieważ są postrzegani jako konkurencja, i często zamyka się im drogę do zatrudnienia w jednej z jednostek podstawowych. Dzieje się tak, ponieważ to wydział czy centrum badawcze jest $\mathrm{w}$ praktyce miejscem zatrudnienia, a nie uczelnia. Oznacza to, że w nowej ustawie powinna zostać zapewniona daleko idąca autonomia i swoboda organizacyjna, tak aby rektor i Senat w prosty i szybki sposób mogli podejmować decyzje dotyczące wewnętrznej struktury uczelni oraz stwarzać możliwości zarówno dla mobilności poziomej pomiędzy jednostkami, jak i szybkiego znajdowania miejsca pracy dla wybitnych badaczy przychodzących z zewnątrz.

- Wartym rozważenia pomysłem jest także rozdzielenie w jednostkach podstawowych kwestii dydaktycznych i naukowych. Osoby zarządzające prowadzeniem danego kierunku studiów powinny mieć swobodę w doborze obsady. Ta wewnętrzna konkurencja wymogłaby konieczność prowadzenia badań naukowych, ponieważ to badacze, którzy mają styczność z najnowszymi wynikami naukowymi, byliby najbardziej pożądanymi wykładowcami. Ponadto zdecydowana większość studentów chciałby mieć do czynienia z akademikami, których pozycja naukowa jest wysoka lub bardzo wysoka. Tak dzieje się w wielu państwach świata. Nie ma żadnych powodów, dla których w Polsce miałoby się to nie udać.

- Jak w każdej dobrze zarządzanej instytucji konieczne jest wspieranie czy nawet „hołubienie” tych, którzy przynoszą uczelni najwięcej korzyści i wpływają 
na jej rozpoznawalność światową. Wymaga to stworzenia transparentnego systemu administracyjnego, akceptowanego przez innych pracowników, którzy jeszcze nie osiągnęli doskonałości naukowej i może nigdy im się to nie uda, ale dla uczelni są po prostu niezbędni. Bez transparentności i przekonania o wspólnym interesie mogą oni po prostu blokować wprowadzanie zmian. Dlatego też nowa ustawa musi dawać szansę elastycznego zarządzania kadrą i w odróżnieniu do spółek skarbu państwa tworzenia „kominów finansowych”. Najlepsi powinni móc zarabiać kilka, a nawet kilkanaście razy więcej niż średnia. Dotyczy to oczywiście tylko nagradzania za działalność stricte naukową. Niestety, albo może i na szczęście, poziom wynagrodzeń jest nadal najlepszym sposobem zarówno zachęcania, jak i premiowania za osiągnięte wyniki. Wskaźniki rzetelnej oceny działalności naukowej w poszczególnych dziedzinach czy dyscyplinach są łatwo dostępne i raczej nie budzą już kontrowersji.

Te wszystkie działania powinny być realizowane w ramach tzw. uniwersytetów badawczych.

\section{Uniwersytety badawcze - nadzieja czy wyzwanie?}

Jednym z celów obecnie dyskutowanej reformy nauki i szkolnictwa wyższego jest sama potrzeba wydzielenia uniwersytetów badawczych. Jak należy je jednak wyłaniać, aby osiągnąć efekt w postaci zwiększenia liczby bardzo dobrych zespołów naukowych rozlokowanych bardziej równomiernie na terenie Polski? Wielu podpowiedzi dostarcza analiza struktury uczelni uznawanych za najlepsze na świecie. Odwołując się do danych zaprezentowanych na gdańskim Narodowym Kongresie Nauki przez Macieja Żylicza, prezesa Fundacji na rzecz Nauki Polskiej, przy obecnej liczbie studentów żaden polski uniwersytet nie zostanie uznany za „badawczy”. Przykładowo Stanford to „tylko” niewiele ponad 16 tys. studentów, Cambridge 19 tys., Oxford - 22 tys. a Politechnika w Lozannie - 11 tys. studentów. W przypadku polskich uczelni jest to co najmniej dwa, a nawet trzy razy więcej. Oczywiście należy uwzględniać tu również stosunek studentów do zatrudnionych (Students to Staff Ratio), ale i w tym przypadku dla uczelni wchodzących np. do najbardziej prestiżowej Ligi Europejskich Uniwersytetów Badawczych są one o wiele bardziej korzystne, niż udało się to osiągnąć w Polsce. Oznacza to konieczność zaprogramowania oraz przeprowadzenia zasadniczego, ale rozłożonego w czasie zmniejszenia liczby studentów na polskich uczelniach, które chciałyby stać się badawczymi. Dotyczy to w szczególności studiów magisterskich i doktoranckich. Należałoby tu przyjąc zasadę, że prace zarówno magisterskie, jak i doktorskie powstają w zespołach badawczych i są efektem rzetelnie prowadzonych badań naukowych. Oczywiście ich przygotowanie musi zajmować więcej czasu, a więc i więcej kosztować. 
To musiałoby prowadzić do ograniczenia liczby studentów na drugim i trzecim stopniu, ale podniosłoby jakość studiów i samych prac. Wpłynęłoby także na przyspieszenie awansu zawodowego pracowników naukowych, choćby poprzez zwiększenie liczby dobrych publikacji w początkowym okresie kariery. Wiele osób, które mogłyby starać się o granty ERC, zdolność taką uzyskuje dosłownie rok, dwa po upłynięciu terminów, w których mogłyby to zrobić, zatem przyspieszenie momentu „wchodzenia” do obiegu międzynarodowego może przynieść naprawdę istotne korzyści. Takie podejście wymaga jednak zmian zasad finansowania. Wskaźnik kosztochłonności prowadzenia studiów na uniwersytetach badawczych musi być wyższy niż w uczelniach dydaktycznych. Musi im się po prostu opłacać więcej inwestować w poziom kształcenia, zapraszając magistrantów i doktorantów do zespołów badawczych, a następnie wspierać ich w opracowaniu pierwszej ważnej publikacji naukowej. Takie podejście oznacza, że jednym z kryteriów wyboru uniwersytetów badawczych powinno być pokazanie ścieżki zmniejszania liczby studentów na studiach magisterskich i doktoranckich przy jednoczesnym wprowadzeniu obowiązku podniesienia jakości prac będących ich efektem poprzez uznanie, że powinny one powstawać w zespołach badawczych. To prowadzi do kolejnego pytania o inne kryteria wyłaniania uniwersytetów badawczych. Przesądzone zostało, że ma to być otwarty konkurs, w którym będzie mogła wziąć udział ograniczona liczba uczelni. Kryteria wstępne mają być oparte na wynikach parametryzacji. Uczelnie, które spełnią te kryteria, będą mogły, ale nie musiały, przystąpić do konkursu. Trudno sobie jednak wyobrazić, że jakaś uczelnia do tego uprawniona nie podejmie tego wyzwania. Jak zatem powinien wyglądać taki konkurs, którego ogólne założenia powinny znaleźć się w ustawie?

Podstawą formuly konkursu powinno być założenie o różnicach w potencjałach dla prowadzenia badań o przełomowym charakterze na poszczególnych polskich uczelniach. Nie wyobrażam sobie stworzenia jednego, spójnego i uczciwego katalogu kryteriów wyboru, który mógłby stać się podstawą takiego konkursu. Należałoby zatem przyjąć zasadę, że poszczególne uczelnie proponują ścieżkę postępu od stanu w danym momencie do jakiegoś stanu docelowego, np. w perspektywie sześcioletniej. Błędem byłoby ustalanie sztywnych wymogów liczbowych. Lepszym rozwiązaniem wydaje się pokazanie, o jaki zakres dana uczelnia chce poprawić swoją jakość naukową. Na podstawie materiału Zespołu Rektorskiego Uniwersytetu Warszawskiego, jaki został opublikowany na stronie internetowej Narodowego Kongresu Nauki (https://nkn.gov.pl/material-do-dyskusji-wylanianieuniwersytetow-badawczych/), można sobie wyobrazić następujące kryteria, jakie w swoich wnioskach o przyznanie statusu uniwersytetu badawczego powinny zostać wskazane przez uczelnie. Kilka z nich mogłoby wyglądać następująco:

- Zaplanować procentowy wzrost w zakresie cytowań w czasopismach z listy A lub C MNiSW odnotowanych w bazie Scopus oraz Web of Science. Pozwoli to uzyskać wpływ na rozpoznawalność polskiej nauki oraz wymusi inwestycje 
w pracowników naukowych i zespoły badawcze mające ambicje i potencjał do publikowania w najważniejszych czasopismach światowych.

- Zaplanować procentowy wzrost udziału pracowników z danej uczelni w międzynarodowych konsorcjach badawczych realizujących projekty o charakterze doskonałości, a finansowanych ze źródeł zewnętrznych. Pozwoli to zwiększyć kompetencje do uczestnictwa w przełomowych projektach badawczych.

- Zapewnić właściwe wykorzystanie dostępnej infrastruktury badawczej poprzez ich otwarcie na realizację projektów prowadzonych przez zewnętrzne zespoły badawcze, w tym z zagranicy. Celem jest otwieranie się na zewnątrz i ograniczenie kosztów utrzymywania infrastruktury.

- Przyjąć założenie, że uczelnia w okresie 3-4 lat po uzyskaniu statusu uniwersytetu badawczego wystąpi do Polskiej Komisji Akredytacyjnej o zapowiadaną kompleksową ocenę jakości kształcenia. Przyczyni się to do poprawy jakości edukacji akademickiej oraz powiązania prowadzonych badań z kształceniem.

- Zaplanować procentowy wzrost liczby pracowników zatrudnionych na uczelni w zakresie mobilności zewnętrznej (krajowej i zagranicznej). Za mobilność powinien być uznawany co najmniej trzymiesięczny pobyt na innej uczelni notowanej w jednym z rankingów: ARWU, THE, QS lub w rankingu Perspektyw na miejscach od 1. do 20. Zwiększy to umiędzynarodowienie polskiej nauki i pozwoli uzyskać niezbędne kompetencje do ubiegania się o prestiżowe międzynarodowe projekty badawcze.

- Zaplanować procentowy wzrost liczby pracowników zatrudnionych na uczelni, którzy uzyskali tytuł magistra lub/i stopień doktora na innej uczelni krajowej bądź zagranicznej. Pozwoli to ograniczyć „chów wsobny” i otworzyć uczelnie na pracowników z zewnątrz.

- Zaplanować powstanie wewnętrznego systemu finansowego wspierania doskonałości naukowej (granty, stypendia, „start up funds” itp.), stanowiącego odpowiedni procent zwiększonego budżetu uczelni w wyniku uzyskania statusu uniwersytetu badawczego. Ma to na celu wspieranie rozwoju zawodowego pracowników naukowych i przyciąganie zdolnych badaczy z kraju i zagranicy.

- Posiadać otwarty, transparentny, ale także rygorystyczny system rekrutacji i zatrudnienia pracowników zgodny ze standardami HR Exellence in Research.

- Zaplanować procentowy wzrost udziału wszystkich środków na projekty badawcze ze źródeł międzynarodowych (z puli finansowej na naukę, ale bez środków na rozwój infrastruktury) w stosunku do całego budżetu jednostki przeznaczonej na badania. Zwiększyłoby to potencjał do uzyskiwania środków zewnętrznych.

Przy takim podejściu kierownictwo uczelni ma bardzo dużą elastyczność w zakresie planowania procentowego wzrostu w poszczególnych obszarach. Rolą Ministerstwa Nauki i Szkolnictwa Wyższego byłoby ocenianie, czy przedstawiony plan jest wystarczająco ambitny, aby uznać taką uczelnię za zmierzającą w kierunku uni- 
wersytetu badawczego, a więc przyznać jej taki status. Oczywiście plany uczelni powinny być oceniane nie tylko przez urzędników ministerstwa, ale przede wszystkim przez międzynarodowy zespół oceniający, ale z koniecznym udziałem badaczy mających duże doświadczenie w pracy na polskich uczelniach oraz znających polskie realia. Ten sam lub podobny zespół powinien oceniać dokonany progres. Pierwsza ocena miałaby być realizowana w połowie okresu, na jaki został przyznany status uniwersytetu badawczego oraz zwiększone środki na realizację założonych celów. Jeżeli nawet ocena śródokresowa byłaby negatywna, to uczelnia powinna, na zasadzie wygaszania (tzw. rolling grants), uzyskiwać zwiększone środki finansowe do końca realizacji zadania. Należy bowiem założyć, że wiele wprowadzonych działań nie byłoby możliwych do zakończenia natychmiast po uzyskaniu oceny negatywnej. Groziłoby to bankructwem uczelni, która z różnych powodów nie uzyskała zadowalających komisję oceniającą wyników.

Powyższe propozycje, a może tylko kierunki zmian mogłyby zasadniczo zmienić podejście do „uprawiania” nauki w Polsce. Jednocześnie odnalazłaby się w nich zdecydowana większość badaczy, co być może ograniczyłoby ich obawy przed zmianami. Cel tych propozycji jest tak naprawdę jeden - Polska musi znaleźć się w klubie „imperiów wiedzy”, czyli krajów, w których inwestycja w naukę, ale i jej uprawianie na najwyższym poziomie staje się ważnym wyróżnikiem na świecie, co przynosi istotne korzyści społeczne i gospodarcze.

\section{Zakończenie}

Doskonałość naukowa stała się w debacie na temat przyszłości polskiej nauki i szkolnictwa wyższego chyba najczęściej używanym terminem. Oczywiście można skupiać się na dyskusji, czym ona tak naprawdę jest, pytanie tylko po co. Każdy z pracowników naukowych jest w stanie w bardzo szybki i prosty sposób zdefiniować, co ona oznacza w jego dyscyplinie. Dlatego też zachęcam bardziej do tego, aby dyskutować, jak zwiększyć w Polsce liczbę uczelni, zespołów czy badaczy, którzy byliby uznawani przez swoje koleżanki i koledzy za doskonałych naukowo. Kilka z propozycji znajduje się w niniejszym tekście. Czy któraś z nich znajdzie się ostatecznie w nowej ustawie - czas pokaże.

\section{On scientific excellence and research universities in context of Law 2.0}

ABSTRACT. Since mid-2016 a debate has been going on about the necessary changes in the system of science and higher education in Poland. One of its elements is the discussion on how to improve the level of scientific excellence, recognition of Polish science worldwide and its internationalization. The paper puts forward proposals for several solutions helping to attain those goals. This concerns 
in particular an increase in the number of prestigious international grants redeemed at Polish universities, particularly those awarded by ERC. The paper also proposes criteria for selection of the universities that might obtain additional financing for transformation into research intensive universities. They would be based on demonstration of the path of the changes to be carried out, which require additional financing. The main aim of the paper is to propose specific solutions that might be applied in a new legislation regulating the issues of science and higher education.

KEYWORDS: science, ERC grant, research intensive university, excellence in science

CYTOWANIE: Duszczyk, M. (2017). O doskonałości naukowej i uniwersytetach badawczych w związku z Ustawą 2.o. Nauka i Szkolnictwo Wyższe. 2(50): 259-266. DOI: 10.14746/nisw.2017.2.13.

MACIEJ DUSZCZYK - dr hab. Prorektor do spraw naukowych Uniwersytetu Warszawskiego, członek Rady Narodowego Kongresu Nauki przy Ministrze Nauki i Szkolnictwa Wyższego, członek Rady Naukowej Ośrodka Badań nad Migracjami UW. W latach 2014-2016 członek Komitetu Polityki Naukowej (przewodniczący: październik 2015 - marzec 2016). W latach 2008-2011 członek zespołu doradców strategicznych Prezesa Rady Ministrów Donalda Tuska. W latach 2012-2014 kierował pracami merytorycznymi zespołu ds. wypracowania polskiej polityki migracyjnej w Kancelarii Prezydenta RP. Profesor wizytujący na uniwersytetach Marcina Lutra w Halle-Wittenberg oraz Friedricha Schillera w Jenie.E-mail: m.duszczyk@uw.edu.pl. 